\title{
Павло Бартусяк
}

\section{КОНЦЕПТУАЛЬНІ УМОВИ («) МОНАДОЛОГІЇ (»)}

Вельми часто філософію Ляйбніца представляють як плюралістичну онтологію [див., наприклад, Баумейстер, 2012], а монадологію - як теорію множин ${ }^{2}$. Деякою мірою це справедливо. Адже світ виражається кожною монадою по-різному, кожна «редагує» світ на свій копил, кожна є окремою одиницею у множині простих субстанцій. Але кожна монада виражає увесь світ лише в ідеалі. Насправді ж вона виражає тільки певну ділянку, певний департамент, які, в сукупності, утворюють і зображають ціле - світ. Множинність монад $є$ умовою функціонування світу як цілісності, множинність або розмаїття світу - умовою функціонування монади як єдності. Монада - це наче пазл картини Світу, який, якщо його не уявити в єдиній системі, не матиме жодного значення і застосування. Згідно з теоремою Кантора, потужність довільної множини є меншою, ніж потужність множини всіх ії підмножин. Ляйбніцева філософія може слугувати вельми вдалою демонстрацією цієї теореми. Так, можна погодитись із тим, що вона $\epsilon$ плюралістичною, як й із тим, що монадологія говорить про множинне, однак - мовою одиничного. Плюралізм чи множинність у Ляйбніцевій філософії не наділені жодною онтологією, вони - радше певний ефект, ілюзія точки зору, розташованої у невідповідному місці. Потужність Світу як певної множини є меншою ніж потужність множини усіх його елементів монад. I, передусім, тому, що світ усуціль залежить від «рішень» монад, від їхніх пот гнення і потягу (appétition i appétit), від рівня досконалості, від ділянки, яку вони освітлюють. Множинний світ $є$ багато у чому світом можливим, він може бути, а може й не бути, його доля цілковито узалежнена від рішення Простої субстанції.

Монадологія, на перший погляд, є вченням про монади, інструкцією, в якій описується їхнє значення і функціонування. Але це не зовсім так. Монадологія як теорія $\epsilon$ передусім комплексним вченням про Світ, інструкцією, що описує будову і функціонування Світу-Машини. У творах Ляйбніца, зокрема в «Монадології», часто використовується ідея машини. Згідно зі вченням німецького філософа, світ функці-

(C) П. Бартусяк, 2013

${ }^{1}$ У заголовку статті слово монадологія, узяте в задужковані лапки, вказує водночас на твір і на теорію, що мають таку назву.

${ }^{2}$ Німецький математик Георг Кантор (1845-1918) для побудови теорії множин використовував вчення про монади. Більше того, термін «монада» був запозичений цією теорією. Під множиною Кантор розуміє будь-яке множинне, яке можна мислити как єдине, тобто будь-яку сукупність певних елементів, яка може бути зв'язаною в одне ціле за допомоги певного закону. Таким елементом у теорії Кантора і є монада. Інколи математик називає множинне єдиною річчю. Множина елементів-одиниць утворює нову одиницю-множиу. 
онує автономно, він самодостатній як утворення. Як машина, він складається 3 безлічі простих частин/запчастин, кожна з яких по-своєму виражає і відображає ціле. Кожна деталь Світу-Машини має індивідуальні ознаки і функціональні характеристики. Коли Ляйбніц пише про монади, то насамперед йдеться про прості сутності елементи світу, про його деталізацію, частини і їхню [у ньому] пов'язаність.

Будь-яка оригінальна філософська концепція наповнена більше внутрішньо, ніж зовнішньо, і спроби розглядати тільки зовнішній бік ${ }^{3}$ призводять до, щонайменше, спрощення іiі змісту. «Монадологію» традиційно асоціюють 3 монадою. Вона - наче фасад Ляйбніцевої концепції, який усі впізнають і називають однаково, як останній рубіж, по той бік якого, здається, відсутній будь-який концептуальний зміст. До цього, зрештою, схиляє сама «Монадологія», адже вона починається з визначення монади як простої субстанції, головні характеристики і види якої описуються i урізноманітнюються поступово, від розділу до розділу. Верховна субстанція - Бог $є$ передусім такою простою субстанцією (§ 47), а вже потім джерелом існування усіх похідних монад. А ще згодом, у $\S 53$, Ляйбніц пише, що в ідеях Бога міститься нескінченна кількість можливих всесвітів, з яких може існувати лише один. Виходить, що Бог, з одного боку, є джерелом існування усіх монад, з іншого, Він $\epsilon$ творцем місця, у якому вони діють, творцем світу. Монаді, як іiі зображено на початку «Монадології», передує вибір світу, у якому вона функціонуватиме, передують ідеї можливих всесвітів, один з яких вона виражатиме. Це, так би мовити, § 0 «Монадології», iї умова, яку ми і спробуємо концептуально означити.

Однак умова виникнення не є єдиною, вона неодмінно доповнюється умовою способу перебування монад у світі, це як зміст і форма, генеза (текст) і контекст. У 2005 році у Парижі вийшло окремою книгою зібрання декількох статей про «Монадологію» під назвою «Монадологія Ляйбніца. Генеза і контекст». У цих дослідженнях, зокрема в статтях «Конституювання концепту монада» Мішеля Фішана [Fichant, 2005] та «Монадологія: історія народження» Енріко Пазіні [Pasini, 2005], розглядаються витоки формування концепту монади та умови створення теорії, яка їі описує, себто (") монадології (»), або, як іï називає Фішан, «thèse monadologique ${ }^{4}$ [Fichant, 2005: p. 31]. Конституювання концепту [монади] Фішан розділяє на два рівні: 3 одного боку, системне конституювання, що конструює консистенцію концепту, показуючи, яким чином внутрішня зв'язність компонентів концепту інтегрує його до єдиної доктрини, з іншого ж, - генетичне конституювання, яке виявляє спосіб, у який концепт був сформований і розвинутий. Досліджуючи генетику монади, Фішан звертається до ранніх текстів Ляйбніца, наприклад, до «Дискурсії про метафізику» [Leibniz, 1978c], де, пише він, індивідуальна субстанція не є монадою ${ }^{5}$. Але логіка

3 Зовнішній розгляд - це передусім огляд головних характеристик, понять і термінів тієї чи тієї філософської концепції, виокремлення загальної проблематики і опис ії̈ значення в межах історикофілософського процесу. Прикладами таких розглядів $\epsilon$, наприклад, дослідження Майкла Дж. Фатча «Ляйбніцева метафізика часу і простору» [Futch, 2008], у якому хронологічно розглядається Ляйбніцева концепція крізь призму тієї ії частини, яка говорить про час і простір; книга Крісті Мерсер «Ляйбніцева метафізика. Ії витоки і розвиток» [Mercer, 2004]; праця Ентоні Севіла «Ляйбніц і Монадологія» [Savile, 2000]. У ній автор подає загальну характеристику ключових термінв Ляйбніца: Бог, прості субстанції, природа монад, перцепція і аперцепція, світи, матерія тощо.

4 «Монадологічна теза» (фр.)

${ }^{5}$ На думку Фішана, субстанційні форми у «Дискурсії про метафізику» переважно визначають те, як саме і якою мірою тіла можуть бути субстанціями. Індивідуальні субстанції «Дискурсії...» нічого не кажуть про множинне й єдине, як і про складене й просте. 
філософії Ляйбніца не завжди збігається з логікою іiі викладу у текстах. Це ми побачили на прикладі «Монадології», де Бог як творець з'являється тільки у $\$ 43$. Безумовно, індивідуальна субстанція «Дискурсії...» не є монадою «Монадології». Але остання, окрім усього іншого, є індивідуальною субстанцією. «Монада» остання і остаточна версія простих індивідуальних сутностей у філософії Ляйбніца, і саме від неї, від її особливостей, описаних у «Монадології», ми будемо відштовхуватись. Згадані автори досліджували текстуальну генезу монади, етапи ії формування як концепту, ми ж зосередимось на дослідженні генези монади як елементу світу, розглянемо філософський зміст двох умов: зародження місця іï функціонування (умова 1) та самого ії функціонування (умова 2).

Deus ex machina - зовнішній до ситуації фактор, що кардинально впливає на іiі перебіг. Попередній розбір ситуацій у філософії Ляйбніца показав, що такий прийом філософом не застосовувався. Бо все взвємопов'язане у кожному із можливих світів. Найнепомітніший рух, спричинений в одному місці, поширюється якнайдалі, впливаючи на інші. «Адже маємо знати, що усе пов'язано у кожному із можливих Світів: Всесвіт, яким би він не був, є єдиною суцільністю, немов Океан; найменший рух у ньому розносить свою дію на деяку відстань...» [Leibniz, 1978b: p. 107].

Що означає цей принцип? Пов'язаність - умова, за якої усе поширюється, обгортається і розгортається. Усе одиничне у Ляйбніцевій філософії нероздільно пов'язане. Сукупність цих зв'язків, зібрання цих одиниць утворюють, попри те, що реально існують лише останні, «видиму» множинність, плюралізм монад і можливих світів. Але щойно ми намагаємось збагнути сенс множинного Ляйбніцевого світу, множинність як така зникає, перед нами лише одиниці, пов'язані з іншими одиницями, множинне постає лиш загальною моделлю, макетом, який неможливо концептуалізувати.

3 іншого боку, коли ми намагаємось збагнути сенс взаємопов'язаних одиниць і зв'язків усередині них, деталізацію світу, поскладковану у них, ми потрапляємо у прірву нескінченного, бо кожна одиниця містить безліч інших одиниць, кожна 3 яких містить безліч інших одиниць і так до $\infty$. У $\$ 36$ «Монадології» Ляйбніц пише, що у низці взаємопов'язаних речей розіскладання на окремі підстави не може сягнути кінцевої межі деталізації, позаяк у фізичному всесвіті вона нескінченна. У наступному $\S 37$ зазначається, що, аналізуючи кожну підставу на кожному рівні деталізації, ми насправді не просуваємось далі, адже цим можна займатись безперестанно, i, щоб вийти 3 цієї тупикової ситуації, необхідно вивести аналіз достатньої підстави із послідовності деталізацій фізичних речей, іншими словами, потрібно зупинити процес деталізації, але у емінентний спосіб, себто так, щоб це було водночас і початком деталізації. Ця функція Ляйбніцем закріплена за особливою простою субстанцією, яку, як зазначено у § 38, ми називаємо Богом. Монади, з появою особливої Простої субстанції, стають окрім іншого, створіннями. Монада як створіння відсилає з необхідністю до того, що є, водночас, витоком і гирлом іiї деталізації, уникаючи, у такий спосіб, прірви нескінченного. Саме у цьому полягає сенс її нової якості.

Розмаїття світу, як і множинні світи, постає прерогативою Бога, первісної Сдно$c m i$, яка, згідно з Ляйбніцем, є сусбтанцією, відсутньою у вибраному нею світі.

«Око іде иляхами, щзо були прокладені для нього у картині» ${ }^{6}$ [Perec, 1978 : p. 5]. Поціновувач і знавець мистецтва пазлів, французький письменник Жорж Перек

${ }^{6}$ «L'oeil suit les chemins qui lui ont été ménagés dans l'oeuvre». Слова Пауля Клее, що їх Жорж Перек використав як епіграф до преамбули до свого роману «Життя: спосіб застовування». 
пише, що пізнання законів цілого не може виходити із пізнання частин-складників цілого. Можна до знесилення вивчати деталі, але якщо не уявимо їх у системі, зусилля будуть марні. I, що важливо, складність пазлу залежить не від сюжету картини чи вигадливості художника-умільця, а від вимудруваного розрізання картини на частини. Перша артикулящзія (функція): автор замислює і створює картину; друга ${ }^{7}$ : автор задає умову ії функціонування і сприйняття. У цю гру грають не поодинці: кожна дія гравця уже була зроблена виробником, а всі його спроби прораховані і передустановлені автором.

Припустимо, Ляйбніц є таким виробником. Грандіозну картину анонімного Автора він концептуально означив і розрізав на свій манер. Експозицію картини доповнюють детальні інструкції, коментарі, приклади, зроблено усе для того, щоби полегшити завдання гравцеві.

Дотримуючись інструкцій, відтворимо подвійно артикульоване.

\section{Palais de destinées ${ }^{8}$}

У Палаці доль знаходяться уявлення не лише про те, що відбувається, але й про те, що може відбутися. Зваживши, Юпітер обрав. У цьому світі ми можемо побачити усе, що стосується Його.

Чарльз Дарвін вважав, що завдяки теорії еволюції ми наблизилися до відповіді на питання: як виникають нові живі істоти? Із появою «Походження видів» [Дарвін, 2009] розгорілась дискусія: $з$ одного боку, еволюиіоністи, з іншого, креаціоністи. Усе почалося 1860 року в Оксфордському університеті на зібрані Британської асоціації сприяння розвитку науки. Спочатку аргументи креаціоністів були емоційними і просто безпідставними, ось, наприклад, єпископ Вілберфорс, апелюючи до прихильників теорії Дарвіна, питає: якщо ми походимо від мавпи, то, дозвольте уточнити, по лінії діда чи по лінії бабусі? (!)

Хто є Ляйбніц - креаціоніст чи еволюціоніст (здаємо собі справу у тому, що питання не зовсім коректне)? Передустановлена гармонія схиляє радше до першого варіанту.

Де саме Бог замислив передустановлену гармонію? Про це Ляйбніц прямо не пише. У «Монадології» цю гармонію Ляйбніц використовує аж у § 59, а у § 78 пише: «Душа дотримується своїх власних законів, тіло ж - своїх; а стикаються вони завдяки передустановленій гармонії...». У самому кінці «Теодицеї ${ }^{\natural}$, припускаємо,

${ }^{7}$ Подвійна артикуляція (double articulation) - концепт, запропонований Дельозом і Гватарі у творі «Тисяча Плато» [Deleuze, Guattari, 1980]. Ці автори використовували його для опису явища стратифiкації (напр., у геології). Згідно з ними, страта $\epsilon$ подвійно артикульованою, перша артикуляція вилучає з зовнішнього фізичного середовища різноманітні частинки, сукупність яких формує тіло страти, друга ж встановлює стійку структуру страти, чим забезпечує її функціонування.

Поняття «подвійна артикуляція» використовується нами для позначення подвійної функції Бога у Ляйбніцевій філософії: створення світу (а також монад) і створення умов сприйняття i функціонування створеного світу.

8 «Палац доль» (фр.). У $\$ 414$ «Теодицеї» Ляйбніц пише: «Тут, ви бачите палац доль, який я охороняю. Існують уявлення не лише про те, що стається, а і про усе те, що є можливим; i Юпітер, розглянувши їх перед початком світу, що існує, скерував можливості у світах і обрав найкращий 3-поміж усіх» [Leibniz, 1978b: p. 362].

${ }^{9} \S$ 414-416 «Теодицеї». У $\S 53$ «Монадології», де йдеться про присутність в ідеях Бога нескінченної кількості можливих всесвітів, Ляйбніц подає посилання саме на ці параграфи «Теодицеї». 
була спроба дати відповідь на це питання. Ляйбніц доволі неохоче залучав до пояснення природних явищ вищий Розум, намагався до останнього пояснювати їх на основі досвіду, спостереження і логіки. Ляйбніц зазвичай говорить, що душа діє за законами цільових причин, тіло ж - за законами здійснювальних причин чи рухів, а вже потім: «і два царства... гармонізовані між собою». Передустановлена гармонія - це інструкція, згідно із якою функціонує світ, план, складений у palais de destinées, лабораторії Бога. Одначе, однієї гармонії мало, аби припустити існування Палаиу доль. Що ж тоді вказує на доленосну споруду?

Американські біохімік Дін Кеньйон і хімік Гарі Стейнмен наприкінці 60-х років минулого століття написали книгу «Біохімічна передвизначеність» [Kenyon, Steinman, 1969], у якій намагалися зібрати усі відомі на той час факти біохімічної еволюції і систематизувати їх так, щоб не було жодного сумніву в тому, що життя виникло саме собою. На думку авторів, життя могло бути біохімічно передвизначене взаємопритягуванням, що існує поміж структурними цеглинами усього живого - окремими амінокислотами, що формують білки. Згодом, завдяки новим дослідженням, стало зрозуміло, що амінокислоти самостійно не можуть формувати потрібну сувору послідовність без участі ДНК. Природний відбір, як інструмент теорії еволюції, можливий тільки за умови розмноження. У такий спосіб, і саме через ДНК, передаються інструкції амінокислотам нового організму.

Інший американський біохімік Майкл Біхі вважає, що клітина, мікробіологічні функції і процеси, які у ній мають місце, були для Дарвіна незбагненою чорною скринею. Чи застосувна теорія еволюції до зазначених процесів? На це питання Біхі відповідає у книзі «Чорна скриня Дарвіна» [Behe, 1996]. Теорія еволюції, попри свою обмеженість, добре пояснювала, наприклад, наявність рудиментарних органів, розмаїття видів, тоді як креаціонізм на кожному етапі залучав до «справи» Сотворителя. У це в науці мало вірилось, тому тривалий час еволюціонізм спочивав на лаврах. Пояснити нововідкриті факти у мікробіології й біохімії теорія еволюції не могла, і перші труднощі, з якими вона зіштовхнулося, стосувалися передусім незвідної складності ${ }^{10}$. Йдеться про таку систему, структурні елементи якої не могли бути сформовані через природний відбір, систему, видалення частин якої призводить до збою у роботі. Ї̈̈ елементи не могли бути вироблені незначними послідовними модифікаціями аналогічних елементів системи попередників, позаяк кожен попередник по відношенню до незвідної складності за визначенням є нефункціональним. Це підводить volens nolens до пропущення існування Intelligent Design ${ }^{11}$. Кеньйон, прихильник теорії спонтанного зародження, біохімічної передвизначеності, згодом змушений був вдаватись до таких припущень теж.

Наскільки неохоче Кеньйон припускав Intelligent Design - можна тільки уявляти, адже таке припущення ненаукове, не може бути підтверджене експериментально. Маємо теорію, яка не дає прогнозу і не передбачає нових гіпотез. Поважав наукові принципи і Ляйбніц, попри те, що поняття верховний Розум у його часи було популярним. Про Intelligent Design, себто про ідею передустановленої гармонії, він відкрито не пише, вуалюючи іiі історією Юпітера, Теодора, Секста. Тут Ляйбніц постає еволюціоністом, позаяк у нього світ засновується на самодостатніх простих сутностях, які у змозі самостійно підтримувати роботу світу й урізноманітнювати

\footnotetext{
${ }^{10}$ «Irreducible complexity», термін Біхі.

11 «Розумний задум» (англ.).
} 
його; позаяк через рацію проникаємо у глибини мікробіологічного світу і відкриваємо безліч законів, які вказують на самодостатність там наявною життя. Але, водночас, ми виносимо з Ляйбніцевої концепції й ідею Intelligent Design, адже мікрочастки, які описуються відкритими законами, неможливо звести до їхніх менших версій без втрати їхньої усталеної функціональності, а деталізацію світу неможливо припинити без їі виведення за межі послідовності фізичних речей.

Палада показує Теодору ті місця, де знаходиться не той Секст, якого він бачив, а схожий Секст, з властивостями, притаманними справжньому Сексту, але без тих, яких він може набути у майбутньому. Словом, ти знайдеш «Секстів будь-якого штибу $i$ нескінченних ладів» [Leibniz, 1978b: p. 363]. Множинність Секстів не залежить від самого Секста. Бог допустив його існування, і лише у межах цього рішення той може «еволюціонувати». Завдяки передустановленій гармонії Секст має ті чи інші природні задатки. Завдяки загальному плану Всесвіmy [ibid., p. 160] він потрапляє у найрізноманітніші ситуації, у яких ці задатки розвиваються або, навпаки, деградують. Одне рішення Бога розміщує Секста у найкращому зі світів і наділяє свободою, друге каталогізує його життя і записує у «великому томі писань» [ibid., p. 363].

Терміном транскрипиія біохіміки позначають процес синтезу РНК з ДНК, яка транспортує скопійований генетичний код у рибосому, де відбувається синтез білка шляхом приєднання амінокислот у послідовності, заданій кодом. Передустановлена гармонія є тією матрицею, за зразком якої відбувається транскрипиія, вибудовуються події у найкращому зі світів. Нескінченна кількість таких матриць зберігається у palais de destinées, нескінченна кількість можливих світів у кожному з палацових приміщень: «Богиня ввела Теодора в одне з приміщень: коли він увійшов туди, ие вже було не приміщення, а світ» [ibid.]. Ляйбніц надіється, що «Паллада не зле фігурально зобразила те, щио називають наукою простого розуміння [science de simple intelligence ${ }^{12}$ ] (тобто як те, щьо розглядає усі можливості), у якій потрібно, зрештою, шукати джерело речей» [ibid., p. 365].

Ці останні рядки «Теодицеї» - свого роду настанова. Якби Кеньйон свого часу визнав цей постулат, чи був би він настільки впевнений у спонтанній біохімічній nередвизначеності? Урешті-решт, science de simple intelligence привела його до Intelligent Design, яке фактично корелює із Ляйбніцевим great design, із великим задумом ${ }^{13}$.

\section{Confusion $^{14}$}

Позитивною особливістю стилю Ляйбніца є те, що, ставлячи запитання, він точно знає як відповісти. Навіть складається враження, що свої запитання він формує лише коли накопичино вдосталь фактів. Свої твори він починає не із фундаментальних запитань, а $з$ демонстрації спостережень, роздумів, медитацій, $з$ викладу фактів,

12 Французький термін intelligence є досить багатозначним. У гносеології XVII ст., починаючи 3 Декарта, ним позначали певну пізнавальну здатність (аналог лат. intellectus, іноді - ingenium), процес розуміння, а також його результат, себто досягнуте розуміння. Інколи, слідом за схоластами, Ляйбніц позначає ним істот, обдарованих інтелектом (в таких випадках ми зазвичай послуговувались відповідником «інтелігенція»). Отже, у зв'язку з цим терміном, ми змушені вдаватись до суто контекстного перекладу.

13 «Grand dessein» [Leibniz, 1978b: p. 167].

14 «Змішаність» (фр.). 
постулатів, принципів. Коли він формулює своє славнозвісне запитання: «Чому радще є щзось, а не ніщзо? [Ляйбніц, 2008: с. 34], то перед тим закликає: «нині ж слід піднятися до метафізики, послуговуючись великим принципом ... нічого не відбувається без достатньої niдстави» [ibid.]. Ляйбніц робить усе можливе для створення таких умов, які сприяли би формуванню відповідей, він дбає передусім про це. Запитання «Чому радме є щзось, а не ніщзо?» Гайдегер перетворив на основне питання метафізики: «питання за рангом перше, позаяк $\epsilon$ найширшим, найглибшим $i$ найпочатковішим... ${ }^{15}$ ». Годі уявити, щоб Ляйбніц у такий спосіб обгрунтовував постановку запитань. Його текстові властива неабияка скромність: «ми маємо право [!] перейнятись таким найпериим питанням: чому радще є щзось, а не ніщо?» [Ляйбніц, 2008: с. 34]. Кажучи «ми маємо право», Ляйбніц, немов умілий адвокат, переходить від «справи до справи», акцентує на тому, що питання найперше! Наче лише він один прикув увагу до не відомих нікому аргументів, до непримітного для всіх сприйняття. Закликає через найперше запитання «присяжних»: оцініть мої спостереження, зробіть, врешті-решт, висновки.

Вміст palais de destinées формують можливі світи. Різниця між ними залежить не від типу структурних елементів, а від того, що вони синтезують. Так і різниця між людьми визначається не самими генами, а тим, як вони функціонують, швидкістю і кількістю вироблених білків. Ця мікроспонтанність формує характер того чи іншого світу, тієї чи іншої людини. На думку Ляйбніца, щомиті нас переповнює нескінченна кількість неусвідомлених сприйняттів. Це відбувається само собою, але - поза межами нашої чуттєвої спроможності. Неусвідомлені сприйняття формують найрізноманітніші сполуки і утворення, які по мірі зростання і зміни консистенції потраплють у павутиння відчуттів. «Не буває так, щоб цей рух не уражав повсякчас наші органи, і шооб у душі не відбувалось ще чогось, йому відповідного, унаслідок гармонії думі й тіла, та иі позбавлені принад новизни враження, щзо перебувають у душі й тілі, не досить сильні, щоби привернути до себе намі увагу й пам'ять, прикуті до об'єктів більи захопливих» [Leibniz, 1978a: p. 47].

Сьогодні генетика дозволяє виявляти специфічні гени, безпосередньо відповідні за ту чи іншу особливість або схильність - генетичні маркери. «Крім того, ціi невідчутні сприйняття позначують [marquent] $i$ конституюють одного й того ж індивіда» [Leibniz, 1978a: p. 48]. Замінимо Ляйбніцеві невідчутні сприйняття генами-маркерами: останні позначають і конституюють самість індивіда. Одна із найулюбленіших метафор Ляйбніца, шум моря, засвідчує: шум цілковито можемо почути тільки якщо почули шум кожної хвилі, попри те, що кожен із цих незначних шумів сприймається не інакше як у сплутаному згромадженні (assemblage confus) ycix інших [ibid., p. 47]. А що станеться, як проігноруємо одну хвилю і вироблений нею шум, як не виявимо особливий ген, який згодом назвемо маркерним, що зумовлює певну особливість, ваду чи недугу? Виявлення генів-маркерів дозволив робити передбачення і генно-інженерні модифікації, а це зміщує усталений попередніми теоріями поріг розвитку організму й, у результаті, з'являються нові можливості для відновлення і продовження його функціональності. Ляйбніц вважає, що щось іззовні має дати нам сигнал звернутись до наших власних теперішніх сприйняттів [ibid.], a то вони пройдуть повз нашу рефлексію, стануть непомітними. «Сто тисяч ніщзо не змогли би виробити щзось» [ibid.].

\footnotetext{
${ }^{15}$ «Die dem Range nach erste, weil weiteste, tiefste und ursprünglichste Frage...» [Heidegger, 1983: S. 3].
} 
Щось складається із чогось. Наймізерніша частка виражає, хоч і плутано, сукупність, яку формує: «...немає нічого необробленого, безплідного, немає смерті у всесвіті, жодного хаосу, жодної змішаності [confusion], окрім позірних ${ }^{16} \gg$. Confusion - це стан речей, радіохвиля, що не входить у діапазон людського відчуття. У цьому найкращому зі світів нас закликали розвіяти confusion, ми повинні розгледіти наймізерніші частки, риси і обставини. У таких умовах зароджується функція Ляйбніцевого концепту point de vие (точка зору), $\mathrm{f}: \mathrm{X} \rightarrow \mathrm{Y}$, де $\mathrm{X}$, себто область визначення, постає, у ширшому сенсі, як найкращий зі світів, у вужчому, - як певна ситуація, що склалась; Y, себто область значення - як, у ширшому сенсі, код передустановленої гармонії (глобальний екстремум), що був заданий у palais de destinées, у вужчому, - як код, що був заданий, наприклад, людиною (локальний екстремум): «чий це портрет: людини, мавпи чи риби; однак, подививиись на нього через циліндричне дзеркало, ми, можливо, виявимо, щчо невиразність зникла, і ми бачимо, щчо це Юлій Цезар» [Leibniz, 1978a: p. 239].

Бог дозволяє людині певною мірою ватажкувати у «ї̈ малому департаменті» [Leibniz, 1978b: p. 197], при цьому Ляйбніц зазначає: «входить Він туди тільки таємно» [ibid.]. Бог «грається (так би мовити) цчими малими Божками» [ibid.], залишаючись невидимим.

У 1923 році російський біохімік Олександр Опарін припустив, що, в умовах первісної Землі, органічні речовини могли виникнути із простих сполук аміаку, метану, водню й води. Хімічні реакції, що відбувались, отримували енергію від сонця і атмосферних розрядів (блискавок). Сформована органіка нібито поступово накопичувалась у давньому океані - добіотичному бульйоні, де і зародилось життя. Цю теорію взялись доводити американські хіміки Стенлі Мілер і Гарольд Юрі. У 1953 році вони провели відомий (названий згодом на їхню честь) експеримент, у якому імітували умови первісної Землі. Через уже згадану газову суміш вони пропускали електричні розряди, внаслідок чого розпочався процес формування складних органічних сполук, були отримані навіть деякі амінокислоти, попри те, найголовнішого нуклеїнових кислот - отримано не було.

Найкрихітніше щзось, монада опромінює лиш свою територію, через найдрібнішу точку на графіку функції проводимо дотичну, у наймізернішого на світі своя точку зору, у Ляйбніцевому світі стан речей - це, передусім, confusion, адже кожне щзось у світі бачить чітко і виразно те, що ним освітлюється. Позаяк розгледіти Цезаря можемо лише в циліндричному дзеркалі, ми себе трансформуємо, знаходячи ліпшу точку зору, суб'єкт - це те, що приходить до точки зору, що заселилось у ній. Ми конструюємо телескоп «Габл», щоби виявити у найвіддаленіших туманностях космічні тіла, збираємо найнікчемніші порції випромінювання далеченних світил. Дельоз у творі «Складка. Ляйбніц і Бароко», посилаючись на Вайтхеда, констатує: «суб'єкт є не “суб-єктом“, а “супер'єктом”"17. Суб-єкт повинен озброїтись не розмаїттям точок зору, а передусім точкою зору на варіацію. У $\S 83$ «Монадології» Ляйбніц пише: «...Душі, на загал, це живі дзеркала чи образи всесвіту створінь, Уми ж, понад те, є образами самого Божества, чи самого Сотворителя Природи, спроможні пізнати Систему всесвіту і дещо з неї наслідувати через архітектонічні взірці...»

\footnotetext{
${ }^{16} \S 69$ «Монадології».

17 «Le sujet n'est pas un sub-jet, mais un “superjet”» [Deleuze, 1988: p. 27]. Тут використано особливості латинського sub-jectum: суб'єкт - те, що знаходиться під річчю, супер'єкт - те, що знаходиться над річчю.
} 
Всесвіт має свою архітектоніку. Справа не у тому, що ми можемо пізнати ії принципи, а у тому, що $є$ спосіб наслідувати, ідеться про взірцевість, знання системи всесвіту проектує матрицю. Люди не обмежуються спогляданням об'єктів власного зору у його звичному режимі, люди удосконалюють його, щоби пройти крізь confusion.

Амінокислотам, синтезованим під час експерименту Мілера-Юрі, не була притаманна хіральність - властивість молекули бути несумісною зі своїм дзеркальним відображенням, саме у це цілять критики теорії спонтанного зародження. Існують хімічні сполуки, у яких структура і молекулярна маса однакові, а будова і розміщення атомів - різні. Це явище хіміки називають ізомерією. Хіральними ізомерами є переважна більшість біологічно активних макромолекул, у тому числі амінокислоти. Одна форма амінокислот заломлює світло ліворуч, інша - праворуч, одна форма солодка на смак, інша не має жодного смаку. Чому так $є$ у природі й чому це не притаманно штучно синтезованим амінокислотам вчені однозначно ще не відповіли. Хіральні об'єкти не можуь бути зіставлені зі своїми відображеннями у дзеркалі: ані переміщеннями, ані поворотами, ані зміною масштабу.

Хіральними є можливі світи. Один світ заломлює світло ліворуч, інший праворуч. В одному світі Секст учиняє безлад, в іншому він $\epsilon$ щасливим. На думку хіміків, хіральність молекул зумовлює стабільність їхньої структури, забезпечує їхне функціонування. Вибір, протилежний до вибору в іншому світі, забезпечує функціонування свого світу. «Бог, через якесь дивовижне мистецтво, обертає всі вади ичих малих світів на найбільшу оздобу Свого великого світу» [Leibniz, 1978b: p. 197]. Негатив нашого світу є позитивом у світі Бога. Одначе Творець грає у цьому роль не чаклуна, що перетворює одне на інше у невідомий спосіб, він, немов ілюзіоніст на великій сцені, спритно шукає істинну точку зору. «Це як у тих оманах перспективи, де певні гарні малюнки виглядають лише якоюсь мішаниною, аж поки ̈̈х не перенесуть у ту істинну точку, де на них й слід дивитись, або не поглянуть на них за допомоги певного скла чи дзеркала» [ibid.]. Сенс confusion у тому, щоби розвіяти його за допомоги істинної точки зору. Для ілюзіоністів величезне значення має престиж - це коли усі присутні думають, що ілюзія реальна, але ніхто не здогадується у чому секрет. Для Мілера і Юрі «ілюзія», тобто механізм виникнення життя, вельми реальна і очевидна, однак їхній експеримент таємниці не розгадав. Intelligence souveraine захистило свій престиж. Мабуть, саме так Бог «грається... цими малими Божками», залишаючись невидимим.

Певно, найважливішим у філософії Ляйбніца є те, що вибір Бога не випадковий, адже у Palais de destinées усе ретельно обдумане. У світі ж, виборі Бога, передовсім має працювати наука простого розуму, завдячуючи якій з'являється істинна точка зору, можливість подолати випадковість і змішаність, глобальний екстремум іiі функції.

Palais de destinées - місце, де обирається світ. Confusion - умова його функціонування і сприйняття. Перша і друга артикуляція. Наше завдання полягало у тому, щоби відтворити подвійно артикульоване.

Немов великий вибух і туманності у справі формування фізичного всесвіту, вони описують формування і функціонування світу Ляйбніцевого штибу. Не те щоб ми вказали на ключові моменти філософії німецького філософа. Ми, радше, здійснили реактивацію концептів, показали нові факти у науці, які перекроїли установлені Ляйбніцем контури. 
Попри свою абстрактність, Ляйбніцеві положення вказують на щось конкретне, конкретний процес чи ситуацію. Експозицію філософії Ляйбніца варто розпочинати не із загальної моделі, а з відносно простих випадків. Understanding (здатність розуміти) Лок порівнював із оком, яке дає можливість бачити, хоча самого себе воно не бачить (Проба про людську здатність розуміти I, I.1). Потрібна праця і певне мистецтво, щоб око посіло саме те місце, з якого воно бачитиме себе. У «Нових пробах...» Ляйбніца не цікавить, що таке entendement, для нього не надто важливим $\epsilon$ щойно описана інтенція Лока. Для нього entendement - просто інструмент, який, наприклад, допомагає у пошуках місця для істинної точки зору, через яку ми бачимо істинний стан речей. Пошук точки зору, щоби побачити сам інструмент, яким користуємось, у Ляйбніцеві плани не входив.

Ляйбніців Бог - це intelligentia supramundana ${ }^{18}$. У цьому світі, де confusion - природний стан речей, таке розуміння недоступне. Тут потрібна сила розуміти, наука простого розуміння, істинна точка зору, щоби розвіяти confusion і виявити взаємозв'язки, які мають конкретні риси і на щось вказують, щонайменше, на Юлія Цезаря.

\section{СПИСОК ЛІТЕРАТУРИ}

Баумейстер А. Плюралістична онтологія Ляйбніца: на перехресті схоластики і модерну // Totallogy. Постнекласичні дослідження. - 2012. - № 28. - С. 123-132.

Дарвін Ч. Про походження видів шляхом природного відбору. - Львів: Піраміда. - 2009. $548 \mathrm{c}$.

Ляйбніи Г. В. Ф. Принципи природи і благодаті, засновані на раціо // Філософська думка. 2008. - №4. - C. 25-43.

Behe M. Darwin's Black Box. - New York: Free Press, 1996. - 330 p.

Deleuze G., Guattari F. Capitalisme et chizophrénie. V. 2: Mille plateaux. - Paris: Minuit. - 1980. $-645 \mathrm{p}$.

Deleuze G. Le Pli. Leibniz et le Baroque. - Paris: Minuit. - 1988. - 191 p.

Fichant M. Constitution du concept de Monade // La Monadologie de Leibniz. Genèse et contexte. - Paris: Mimesis, 2005. - P. 30-54.

Futch M. J. Leibniz's metaphysics of Time and Space. - Berlin: Springer, 2008. - Series: «Boston Studies in Philosophy of science», vol. 258. $-228 \mathrm{p}$.

Heidegger M. Einführung in die Metaphysik. - Frankfurt am Main: Vittorio Klostermann, 1983. $234 \mathrm{~S}$.

Kenyon D., Steinman G. Biochemical predestination. - New York, London: Mcgraw-Hill, 1969. $301 \mathrm{p}$.

Leibniz G. W. Nouveaux essais sur l'entendement humain // Leibniz G.W. Die Philosophischen Schriften, Bd. V / hrsg. C.I. Gerhardt. - Berlin: Weidmann, 1882. - S. 39-509 (Nachdruck: Hildesheim, New York: Georg Olms Verlag, 1978a).

Leibniz G.W. Essais de theodicée sur la bonté de Dieu, la liberté de l'homme et l'origine du mal // Leibniz G.W. Die philosophischen Schriften, Bd. VI..., 1885. - S. 21-462 (Nachdruck..., 1978b).

Leibniz G.W. Discours de methaphysique// Leibniz G.W. Die philosophischen Schriften, Bd. IV..., 1880. - S. 427-463 (Nachdruck..., 1978c).

Leibniz G.W. Theodicy. - Oxford: Fellow of Trinity College, 1985. - 445 p.

Mercer C. Leibniz's Metaphysics. Its Origins and Development. - Cambridge: Cambridge UP, 2004. $-484 \mathrm{p}$.

18 «Надсвітова інтелігенція» (лат.). 
Pasini E. La Monadologie: histoire de naissance // La Monadologie de Leibniz. Genèse et contexte. - Paris: Mimesis, 2005. - P. 85-122.

Perec G. La Vie mode d'emploi. - Paris: Hachette, 1978. - 699 p.

Savile A. Leibniz and the Monadology. - London: Routledge, 2000. - 239 p.

Стаття одержана редакцією 08.11.2012

\section{Pavlo Bartusyak (Vinnytsia)}

\section{Conceptual conditions of (") Monadology (")}

The article is an attempt to juxtapose the conceptual bases of work "Monadology" with monadology as one of the basic conceptions of Leibniz's philosophy in general. "Monadology" begins with the definition of monade as a simple substance. But is this definition the beginning of monadology as a theory? In $\S 53$ of "Monadology" Leibniz pointed out that in the ideas of God there is an infinite number of possible universes, and only one of them can be actual. So, the choice of the world and the ideas of possible universes both conceptually precede monade as a simple substance. The article analyses these preconditions via Leibniz's concepts of "palace of fates" (palais de destinées) and "confusion" (confusion). The consideration of these concepts is realized in comparison with some scientific theories, including Dean Kenyon's theory of biochemical predestination and Michael Behe's theory of irreducible complexity.

Pavlo Bartusyak, Applicant for PhD in philosophy at the Department of Philosophy of Vinnytsia National Technical University.

Павло Бартусяк, аспирант кафедри філософії Віннищького начіонального технічного університету.

Павел Бартусяк, аспирант кафедры философии Винницкого наџионального технического университета. 